\title{
A Study of Influential Factors in the Adoption and Diffusion of B2C E-Commerce
}

\author{
Rayed AlGhamdi (ال غامدي راد د) \\ Faculty of Computing and IT \\ King Abdulaziz University \\ Jeddah, Saudi Arabia
}

\author{
Ann Nguyen \\ School of ICT, Griffith University \\ 170 Kessels Rd, Nathan \\ QLD 4111, Australia
}

\author{
Vicki Jones \\ School of ICT, Griffith University \\ 170 Kessels Rd, Nathan \\ QLD 4111, Australia
}

\begin{abstract}
This paper looks at the present standing of ecommerce in Saudi Arabia, as well as the challenges and strengths of Business to Customers (B2C) electronic commerce. Many studies have been conducted around the world in order to gain a better understanding of the demands, needs and effectiveness of online commerce. A study was undertaken to review the literature identifying the factors influencing the adoption and diffusion of $\mathrm{B2C}$ e-commerce. It found four distinct categories: businesses, customers, environmental and governmental support, which must all be considered when creating an e-commerce infrastructure. A concept matrix was used to provide a comparison of important factors in different parts of the world. The study found that e-commerce in Saudi Arabia was lacking in Governmental support as well as relevant involvement by both customers and retailers.
\end{abstract}

\section{Keywords-e-commerce;adoption; B2C; Saudi Arabia}

\section{INTRODUCTION}

Saudi Arabia has a large and growing ICT marketplace. Yet, despite its size and rapid growth, progress in e-commerce activities is relatively slow [1-3]. The Saudi Government introduced e-commerce in 2001 in response to the fast expansion of e-commerce throughout the world. A permanent technical committee for e-commerce was established by the Saudi Ministry of Commerce. However, this Committee no longer exists, and from 2006, e-commerce supervision and development has been managed by the Ministry of Communications and Information Technology (MCIT). Unfortunately, there has been little progress since then [4].

\section{FACTORS INFLUENCING THE ADOPTION AND DIFFUSION OF B2C E-COMMERCE}

Around the world, many studies in online commerce have been conducted in order to gain a better understanding of its strengths and challenges. Research into the factors influencing the adoption and diffusion of $\mathrm{B} 2 \mathrm{C}$ e-commerce tends to discuss these factors as belonging to one or more of four categories. These include: businesses, customers, environment and government facilitation.

\section{A. Factors influencing business' adoption of B2C e-} commerce

The literature discusses various issues that influence businesses to adopt B2C e-commerce. The highlighted issues in this review include

- $\quad$ organization e-readiness
- competitive pressure

- $\quad$ set-up and maintenance cost

- brand strength

- relative advantage of using e-commerce

- consumer purchasing power

- Privacy and Security

- type of products

- Resistance to change

\section{B. Factors influencing customers to purchase online}

The literature discusses various issues that influence consumers to purchase online. The highlighted issues in this review include

- lack of trust due to security/privacy concerns

- reluctance to use credit cards

- language barriers

- $\quad$ preferences for in-store shopping

- good quality of e-commerce websites

- lack of product trial / inspect by hand

- relative advantage (prices, convince etc)

- familiarity of products/seller's good reputation

C. Environmental factors influencing the rate of $\mathrm{B} 2 \mathrm{C} e$ commerce adoption and diffusion

Environmental factors affect the online environment and ecommerce activities, and as a result, also affect businesses and customers. This means that these factors are influential when businesses choose to adopt e-commerce and when customers decide to start trading using e-commerce. The most highlighted issues include

- ICT infrastructure

- online payment mechanisms

- the degree of credit cards penetration

- legislative and regulatory framework

- logistics Infrastructure

- $\quad$ education and awareness

D. Government intervention and its influence to the rate of B2C e-commerce adoption

Throughout the World, governments tend to encourage and support the development of e-commerce. Also, as governments gain a larger Internet presents, their role often changes from simply informational to transactional. As a result, the government becomes both supplier and consumer, 
therefore contributing to the growth of e-commerce [5]. Using e-commerce also means that government departments can reach more customers, with faster service in a more economical way [6].

In Saudi Arabia, there are relatively few studies which identify business, consumers, and government factors. Most of the studies conducted, concentrate on environmental factors.
Similarly with Developing Nations and the Gulf Region, the majority of studies have also focused on the environmental factors. However, studies conducted in Developed Countries tend to concentrate mainly on business and, to a lesser degree, government and environmental factors, with a smaller percentage on customers. This correlates with the fact that the environment, or e-commerce infrastructure, is already well established in these countries.

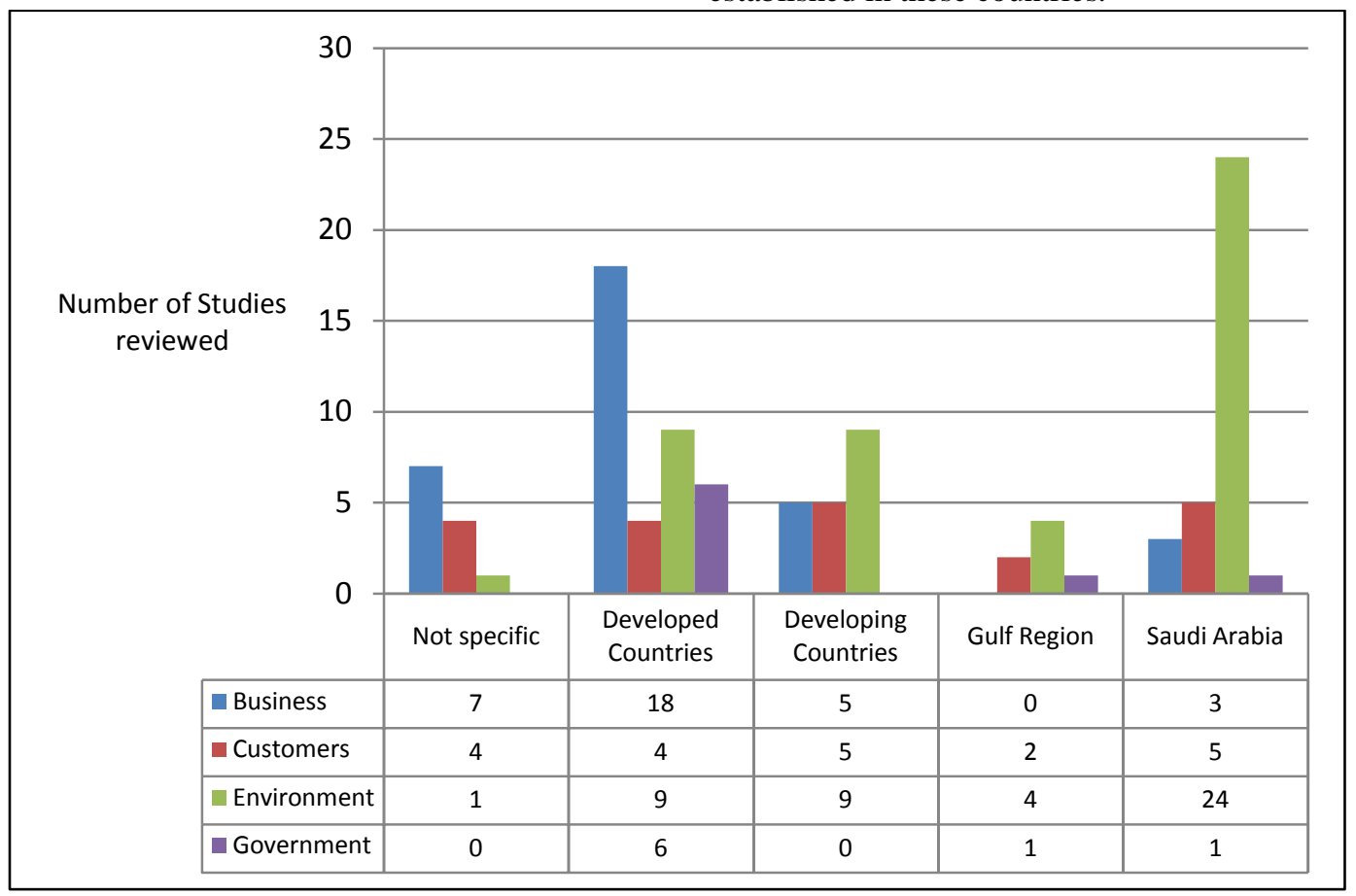

Figure 1

Factors and associated Studies which have influenced the adoption and diffusion of B2C e-commerce

The factors, which have influenced the adoption and diffusion of $\mathrm{B} 2 \mathrm{C}$ e-commerce in research literature, are summarized in Table I (see the appendix). These factors and associated studies are further identified in Figure 1.

A study was undertaken to review the literature identifying the factors influencing the adoption and diffusion of B2C ecommerce. The review is divided into four sections: businesses, customers, environmental and governmental factors (see Table I, in the appendix).

A concept-centric structure is used to enable the separate influencing factors to be associated with the geographical context of the studies reviewed. The resulting concept matrix was then be used to provide a comparison of important factors in different parts of the world. The studies covered the geographical locations of: not specific, developed countries, developing countries, Gulf countries and Saudi Arabia. This division helps to compare different nations and identify similarities and differences (Figure 1).

In regards to Developing Nations, the Gulf Region and Saudi Arabia, the environment (e-commerce infrastructure) is not yet fully established, so is an important factor influencing the adoption and diffusion of $\mathrm{B} 2 \mathrm{C}$ e-commerce. These figures also suggest that governmental support should be a high priority for e-commerce development. By contrast, the high level of readiness in e-commerce environment in Developed Countries leads most studies to concentrate on the businesses and why they might not be selling online when the e-commerce environment is ready for them.

\section{E-GOVERNMENT IN SAUDI ARABIA}

E-government and e-commerce share some similarity in terms of transaction requirements. Therefore, development in e-government can serve as an engine to power e-commerce development [5]. The similarity between e-government and ecommerce is that both of them depend on ICT infrastructure, online payment systems and mailing/post systems to reach their users/customers and deliver their services/products $[7,8]$.

In 2003, a decision was taken by the Saudi Government to start work on e-government; however, a committee for egovernment was established and the actual work started in $2005[9,10]$. With cooperation of three government entities (The Ministry of Communication and Information Technology (MCIT), the Ministry of Finance and the Communication and IT Committee (CITC)), an e-government program called 'Yasser' was launched in 2005 [7]. This program acts as an umbrella for all e-government activities, procedures, legislations and all related issues [10]. An e-government plan was set up with the following vision "By the end of 2010, everyone in the Kingdom will be able to enjoy from anywhere 
and at any time - world class government services offered in a seamless user friendly and secure way by utilizing a variety of electronic means" [7]. However, this vision has not been achieved as set up in a timely manner, which means the plan was not realistic [10]. The main problem, which was not taken into consideration, was the ICT infrastructure and assessing the e-readiness of the different government departments [11-14]. As a result, an e-government second action plan with the vision: "Enable use of efficient, integrated customer friendly and secure multiple e-Government services" (covering the period 2012-2016) has been launched; considering human resource training and development, promote cooperation and innovation culture, and maximizing efficiency of e-services provided by government agencies,[15].

\section{GOVERNMENT ROLE IN E-COMMERCE PROMOTION}

Government support takes various forms from country to country; however, government regulation can be critical to supporting e-commerce [16]. Online shopping shows rapid growth in the developed world. Significantly, the South Korean government has played a key role promoting e-commerce. The Malaysian government is encouraging small and medium enterprises (SMEs) to adopt e-commerce solutions, and in Australia, the Government is providing support is various forms [17].

Although Australian online shoppers are increasing, many prominent Australian retailers are still lagging in terms of online sales. An Australian Government report about ecommerce stated that many retailers did not understand the potential benefits of online shopping and were concerned about the set-up and maintenance costs. The government followed by hosting an online retail forum to encourage, assist and inform retailers [17]. Small Business Online (SBO) was announced in the 2009-10 budget granting $\$ 14$ million to help small businesses go online by offering training programs, advice and development of e-business resources [18].

The Government program, AusIndustry, supports business programs and a range of incentives aimed at helping businesses grow [18]. Singapore, South Korea and Hong Kong are also good examples of countries where the government has taken an active role in pushing for e-commerce proliferation [19]. The Singaporean government has been supporting e-commerce in the country since the early ' 90 s. South Korea has a very strong ICT infrastructure, and Hong Kong set up and implemented an Electronic Transactions Ordinance in 2000. The Hong Kong ordinance contributed to future growth in e-commerce by providing for a legal infrastructure, such as the use digital signatures [20].

\section{DISCUSSION/CONCLUSION}

From the study results, it seems that Saudi Arabia is in great need of more Governmental support. The other two areas which need to be increased are the customers and the retailers. Those countries with successful online retailing infrastructures have strong Governmental support. In Saudi Arabia, people tend to feel more confident in business ventures if they are backed by the Government [21]. It would seem logical that once the Government is involved, the element of trust that ensues can encourage customers and retailers to become involved.

A strategic plan needs to be developed to promote online retailing in Saudi Arabia. Based on this research it is apparent that e-commerce in Saudi Arabia is still in its early stages. With Government engagement, the current state of online retailing could transform into a fully integrated online retailing infrastructure. An appropriate method will be proposed in a later publication.

\section{REFERENCES}

[1] S. Alfuraih, "E-commerce and E-commerce Fraud in Saudi Arabia: A Case Study," in 2nd International Conference on Information Security and Assurance Busan, Korea, 2008, pp. 176-180.

[2] CITC (Communications and Information Technology Commission), "IT Report 2010 On the Internet Ecosystem in Saudi Arabia," Communications and Information Technology Commission, Riyadh2010.

[3] R. AlGhamdi, et al., "Government Initiatives: The Missing Key for Ecommerce Growth in KSA," in International Conference on eCommerce, e-Business and e-Service, Paris, France, 2011, pp. 772-775.

[4] R. AlGhamdi and S. Drew, "Seven Key Drivers to Online Retailing in KSA," in Proceedings of the IADIS International Conference on eSociety 2011, Avila, Spain, 2011, pp. 237-244.

[5] C. J. Blakeley and J. H. Matsuura, "E-government: An engine to power e-commerce development," in Proceedings of the European Conference on e-Government, Dublin, Ireland, 2001, pp. 39-48.

[6] K. Layne and J. Lee, "Developing fully functional E-government: A four stage Model," Government Information Quarterly 18, pp.122-136, 2001.

[7] A. AL-Shehry, et al., "The Motivations for Change Towards EGovernment Adoption: Case Studies from Saudi Arabia," in eGovernment Workshop, London, UK, 2006.

[8] R. AlGhamdi, et al., "Strategic Government Initiatives to Promote Diffusion of Online Retailing in Saudi Arabia," in Sixth International Conference on Digital Information Management, Melbourne, Australia, 2011, pp. 217-222

[9] I. Abu Nadi, L. Sanzogni, K. S. Sandhu and P. R.Woods, "Success Factors Contributing to eGovernment Adoption in Saudi Arabia: G2C approach", Saudi International Innovation Conference SiiC 2008 Proceeding, Leeds, UK, 2008, pp. 1-8

[10] O. Alfarraj, et al., "eGovernment initiatives and key factors causing the delay of their implementation in Saudi Arabia," in 5th Conference on Qualitative Research in IT, Brisbane, Australia, 2010, pp. 130-141.

[11] I. Abu Nadi, "Success Factors for eGovernment Adoption: Citizen Centric Approach", LAP LAMBERT Academic Publishing, Gold Coast, Australia, 2010.

[12] O. Alfarraj, et al., "EGovernment Stage Model: Evaluating the Rate of Web Development Progress of Government Websites in Saudi Arabia," International Journal of Advanced Computer Science and Applications (IJACSA), vol. 2, pp. 82-90, 2011.

[13] M. Alshehri, et al., "A Comprehensive Analysis of E-government services adoption in Saudi Arabia: Obstacles and Challenges," International Journal of Advanced Computer Science and Applications (IJACSA), vol. 3, pp. 1-6, 2012.

[14] M. Alshehri, S. Drew, T. Alhussain, and R. Alghamdi, "The Effects of Website Quality on Adoption of E-Government Service: AnEmpirical Study Applying UTAUT Model Using SEM", in J Lamp (ed.), 23rd Australasian Conference On Information Systems (ACIS 2012), Melbourne, Australia, pp. 1-13 (2012).

[15] Yasser eGov Program. (2012, 7 March). The e-Government Second Action Plan (2012 - 2016). Available: http://www.yesser.gov.sa/en/MechanismsandRegulations/strategy/Pages /-second_Implementation_plan.aspx

[16] K. L. Kraemer, et al., "Globalization and National Diversity: ECommerce Diffusion and Impacts across Nations," in Global ecommerce: impacts of national environment and policy, K. L. Kraemer, et al., Eds., ed New York: Cambridge Univ Press, 2006, pp. 13-61. 
[17] DBCDE (Australian Department of Broadband. Communication and the Digital Economy). (2011, 14 May). Online retail forum. Available: http://www.dbcde.gov.au/digital_economy/online_retail_forum

[18] AusIndustry. (2009, 14 May). Small Business Online (SBO). Available: http://www.ausindustry.gov.au/SmallBusiness/SmallBusinessOnline/Pag es/SmallBusinessOnline.aspx

[19] M. Nair, "The E-commerce Ecology: Leapfrogging Strategies for Malaysia," in ICT Strategic Review 2010/11 E-commerce for Global Reach R. Ramasamy and S. Ng, Eds., ed Putrajaya, Malaysia: PIKOM (The National ICT Association of Malaysia), 2010, pp. 193-211.

[20] R. Wu, "Electronic Transactions Ordinance - Building a Legal Framework for E-commerce in Hong Kong," The Journal of Information, Law and Technology (JILT) http://www2.warwick.ac.uk /fac/soc/law/elj/jilt/2000_1/wu/

[21] R. AlGhamdi, S. Drew, T. Alhussain, “ A Conceptual Framework for the Promotion of Trusted Online Retailing Environment in Saudi Arabia", International Journal of Business and Management, vol 7, no 5, pp. 140-149, 2012.

[22] S. Poon and P. Swatman, "An exploratory study of small business Internet commerce issues," Information \& Management, vol. 35, pp. 9$18,1999$.

[23] D. Grewal, et al., "Internet retailing: enablers, limiters and market consequences," Journal of Business Research, vol. 57, pp. 703-713, 2004.

[24] M. L. To and E. Ngai, "Predicting the organisational adoption of B2C ecommerce: an empirical study," Industrial Management \& Data Systems, vol. 106, pp. 1133-1147, 2006.

[25] D. A. Colton, et al., "Drivers of international e-tail performance: the complexities of orientations and resources," Journal of International Marketing, vol. 18, pp. 1-22, 2010.

[26] J. Kendall, et al., "Electronic commerce adoption by SMEs in Singapore," in Proceedings of the 34th Hawaii International Conference on System Sciences, Hawaii 2001, pp. 1-10.

[27] P. B. Tigre, et al., "Policies and Institutions for E-commerce Readiness: What can Developing Countries Learn from OECD Experience," 2002.

[28] J. Gibbs, et al., "Environment and policy factors shaping global ecommerce diffusion: A cross-country comparison," The Information Society, vol. 19, pp. 5-18, 2003.

[29] K. V. Andersen, et al., "Governance initiatives creating a demand-driven E-commerce approach: The case of denmark," The Information Society, vol. 19, pp. 95-105, 2003.

[30] S. A. Wymer and E. A. Regan, "Factors influencing e-commerce adoption and use by small and medium businesses," Electronic Markets, vol. 15, pp. 438-453, 2005.

[31] K. L. Kraemer, et al., Global e-commerce: impacts of national environment and policy. New York: Cambridge Univ Press, 2006.

[32] S. C. Ho, et al., "A growth theory perspective on B2C e-commerce growth in Europe: An exploratory study," Electronic Commerce Research and Applications, vol. 6, pp. 237-259, 2007.

[33] A. Scupola, "Government Intervention in SMEs' E-Commerce Adoption," in Encyclopedia of Information Science and Technology, M. Khosrow-Pour, Ed., Second ed: IGI Global, 2009, pp. 1689-1695.
[34] M. Tan and T. S. H. Teo, "Factors influencing the adoption of the Internet," International Journal of Electronic Commerce, vol. 2, pp. 5$18,1998$.

[35] A. M. Aladwani, "Key Internet characteristics and e-commerce issues in Arab countries," Information and Management, vol. 16, pp. 9-20, 2003.

[36] A. M. Sleem, "E-Commerce Infrastructure in Developing Countries," in Electronic Business in Developing Countries: Opportunities and Challenges, S. Kamel, Ed., ed USA: Idea Group Inc., 2006, pp. 349-385.

[37] Z. K. Shalhoub and S. L. AlQasimi, The Diffusion of E-commerce in Developing Economies. Cheltenham, UK: Edward Elgar Publishing Limited, 2006.

[38] M. M. Hafez, "The Role of Culture in Electronic Business Diffusion in Developing Countries," in Electronic Business in Developing Countries: Opportunities and Challenges, S. Kamel, Ed., ed USA: Idea Group Inc., 2006, pp. 34-44.

[39] G. R. El Said and G. H. Galal-Edeen, "The role of culture in ecommerce use for the Egyptian consumers," Business Process Management Journal, vol. 15, pp. 34-47, 2009.

[40] K. Al-Rawi, et al., "Driving Factors for E-commerce: Gulf Region Review," Academy of Information and Management Sciences Journal vol. 11, pp. 19-32, 2008.

[41] K. W. Alrawi and K. A. Sabry, "E-commerce evolution: a Gulf region review," International Journal of Business Information Systems, vol. 4, pp. 509-526, 2009.

[42] B. H. Albadr, "E-commerce," Science and Technology, pp. 14-19 (Arabic source), 2003.

[43] S. M. Sait, et al., "E-commerce in Saudi Arabia: Adoption and Perspectives," Australasian Journal of Information Systems, vol. 12, pp. 54-74, Sep 2004.

[44] A. Al-Solbi and P. J. Mayhew, "Measuring E-Readiness Assessment in Saudi Organisations Preliminary Results From A Survey Study," in From e-government to m-government, I. Kushchu and M. H. Kuscu, Eds., ed Brighton, UK: Mobile Government Consortium International LLC, 2005, pp. 467-475.

[45] S. Alwahaishi, et al., "Electronic commerce growth in developing countries: Barriers and challenges " in First International Conference on Networked Digital Technologies, Ostrava, Czech Republic, 2009, pp. $225-232$

[46] F. A. Aleid, et al., "A consumers' perspective on E-commerce: practical solutions to encourage consumers' adoption of e-commerce in developing countries - A Saudi Arabian empirical study," in International Conference on Advanced Management Science, Chengdu, China, 2010, pp. 373-377.

[47] F. A. Aleid, et al., "A suppliers' perspective on e-commerce: Suppliers responses to consumers' perspectives on e-commerce adoption in developing countries - A Saudi Arabian empirical study " in Fifth International Conference on Digital Information Management (ICDIM), Thunder Bay, Canada, 2010, pp. 379-383.

[48] S. A. Al-Hudhaif and A. Alkubeyyer, "E-Commerce Adoption Factors in Saudi Arabia," International Journal of Business and Management, vol. 6, pp. 122-133, 2011.

[49] M. I. Eid, "Determinants of E-Commerce Customer Satisfaction, Trust, and Loyalty in Saudi Arabia," Journal of Electronic Commerce Research, vol. 12, pp. 78-93, 2011. 
TABLE I. FACTORS WHICH HAVE INFLUENCED THE ADOPTION AND DIFFUSION OF B2C E-COMMERCE

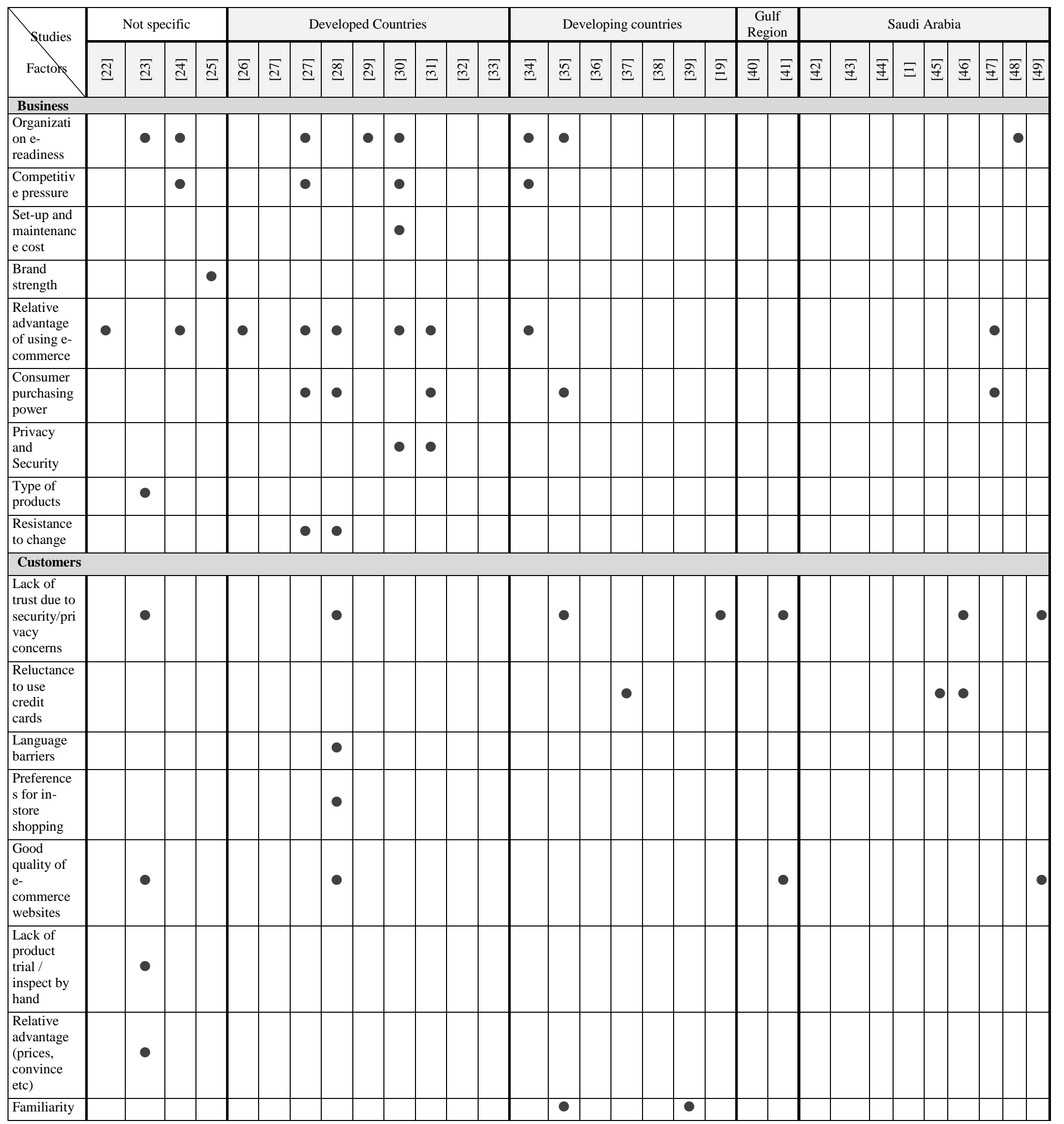




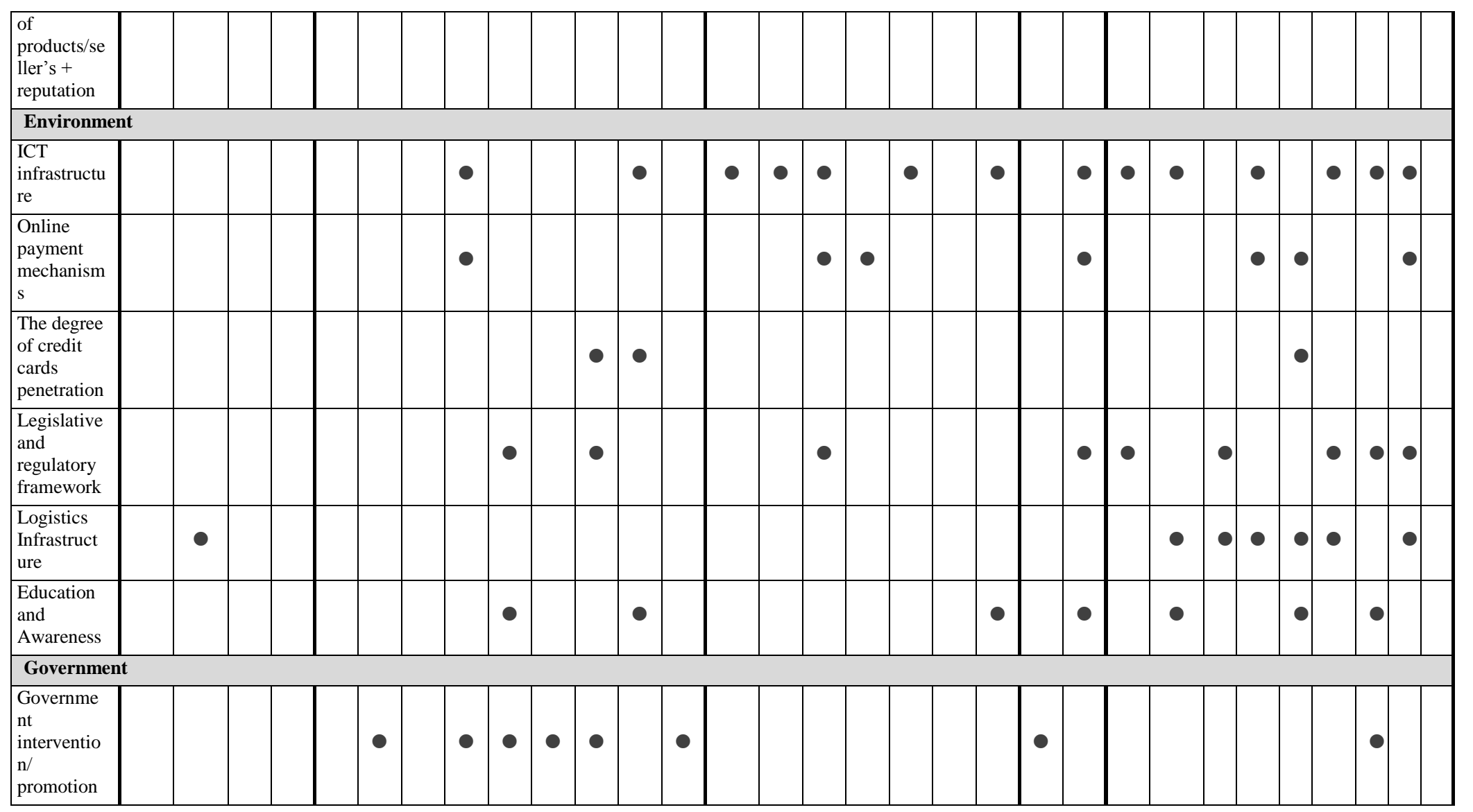

